DOI: 10.33766/2524-0323.92.346-349

УДК 477

В. В. Коваленко,

доктор юридичних наук, професор,

заслужений юрист України,

член-кореспондент НАПрН України,

провідний науковий співробітник

лабораторії авторського права

та інформаційних технологій

Науково-дослідного центру судової експертизи 3 питань інтелектуальної власності

Міністерства юстиції України

(м. Киӥв, Україна)

e-mail:Kovalenko1505@.com

iDhttps://orcid.org/0000-0002-2041-250X

\title{
НОВІ НАУКОВІ ПІДХОДИ ДО ДОСЛІДЖЕННЯ ВСЕУКРАЇНСЬКОГО РЕФЕРЕНДУМУ В СИСТЕМІ РЕФЕРЕНДНОЇ ДЕМОКРАТІЇ
}

Рецензія на кн.: Стефанчук Р. О., Федоренко В. Л. Всеукраӥнський референдум у системі референдної демократії : монографія. Одеса : Видавничий дім «Гальветика», 2019. 252 c.

Рецензія підготовлена на монографію «Всеукраїнський референдум у системі референдної демократії», авторами якої є доктори юридичних наук, професори Р. Л. Стефанчук та В. Л. Федоренко. У монографії розкривається процес утвердження всеукраїнського референдуму в системі референдної демократії.

Монографія є вагомим здобутком не лише для вітчизняної правничої науки, а й теоретико-методологічною основою для прийняття та реалізації майбутнього закону про здійснення народовладдя через всеукраїнський референдум.

Ключові слова: всеукраїнський референдум, народовладдя, голосування, система референдної демократії.

Проблематика всеукраїнського референдуму в незалежній Україні зберігає свою актуальність із часу прийняття 3 липня 1991 року першого спеціального Закону України «Про всеукраїнський та місцеві референдуми» до сьогодення, коли Верховна Рада України IX скликання ухвалила в першому читанні влітку 2020 року проєкт Закону про народовладдя через всеукраїнський референдум (реєстр. № 3612). Всеукраїнський референдум 01 грудня 1991 року, на якому громадяни України переконливо проголосували за незалежність України, став актом усенародного національного державотворення.

Утім, подальші спроби використати потенціал всеукраїнського референдуму для розбудови національної державності та легітимізації важливих для су-

(C) Коваленко В. В., 2020 
спільства рішень виявилися невдалими. Ба більше, із 2018 року, коли Конституційний Суд України визнав Закон України «Про всеукраїнський референдум» неконституційним, громадяни України фактично позбавлені правових механізмів реалізації свого права на референдуми, утвердженого в ст. 38 Конституції України. Однак, потреба проведення всеукраїнського референдуми для вирішення найбільш доленосних для України питань, на наш погляд, зберігає свою актуальність. Про це, зокрема, свідчить й увага законотворців, науковців та експертів до прийняття й реалізації нового закону про всеукраїнський референдум, а також до розроблення та затвердження парламентом низки інших законопроектів у сфері безпосередньої реалізації народовладдя: про місцеві референдуми, про законодавчу ініціативу та ін.

Законодавче забезпечення реалізації народовладдя через всеукраїнський референдум є важливим, але не вичерпним кроком щодо утвердження та розвитку цього інституту безпосередньої демократії. Очевидно, однією з невдач у реалізації права громадян України на ініціювання та проведення громадянами України всеукраїнського референдуму є слабкий розвиток референдної демократії як ідеології, теорії та практики цього виду безпосереднього народовладдя. Тому прийняття Закону про народовладдя через всеукраїнський референдум (реєстр. № 3612) вимагає подальшого науково-методологічного забезпечення його сутності, змісту та механізмів реалізації. У цьому контексті важливим кроком став вихід у минулому році наукової роботи Р. Стефанчука та В. Федоренка, присвяченої питанням теорії, історії та методології всеукраїнського референдуму як складової референдноїдемократії в Україні та за кордоном, яка не лише узагальнила та систематизувала попередні напрацювання цих учених, а й має прогностичний характер щодо розвитку інституту загальнонаціональних референдумів у сучасному світі.

У першому розділі рецензованої монографії грунтовно розкрито сутність (походження) та зміст референдумів, подано особливості генезису та еволюціонування трьох основних моделей референдної демократії у світі: швейцарської, американської та французької. Дві з них (за винятком американської), починаючи 3 XIX ст., примножились загальнонаціональними референдумами, які стали легітимним інструментарієм національного державотворення та конституційної правотворчості. Крім того, показано особливості розквіту і всесвітнього поширення референдної демократії (у кін. XIX ст. - XX ст.) та вплив загальнонаціональних референдумів на легітимізацію транзиту колишніх радянських і соціалістичних держав Центральної та Східної Європи, у т.ч. України, у незалежні й демократичні держави. Авторами роботи також проаналізовано кризу референдної демократії у XXI ст. та обгрунтовано потребу трансформації її цінностей і сенсів у політико-правових реаліях сьогодення.

Водночас, автори монографії «Всеукраїнський референдум у системі референдної демократії» не обмежуються дослідженням загальнонаціональних референдумів і референдної демократії лише в їх ідеологічному та теоретико-правовому сенсі. 
Другий розділ цієї наукової розвідки присвячено проблемам теорії та практики всеукраїнського референдуму як важливого інституту конституційного права. У ньому обгрунтовано визначення всеукраїнського референдуму, наведено сутнісні ознаки цього виду народовладдя, класифіковано та систематизовано основні види загальнонаціональних референдумів в Україні та за кордоном.

Особлива увага дослідників акцентована на предметі та питаннях всеукраїнського референдуму, а також їх допустимості. Розкрито феноменологію т.зв. «формули всеукраїнського референдуму» та обгрунтовано застереження щодо можливих політичних маніпуляцій організаторів референдуму, коли в демократичний спосіб можуть бути легітимізовані неконституційні рішення.

Монографія Р. Стефанчука і В. Федоренка «Всеукраїнський референдум у системі референдної демократії» вирізняється своєю грунтовністю, глибиною досліджуваного матеріалу та, водночас, лаконічністю й доступністю для широкого кола читачів. Зауважимо також, що в цій роботі використано потужну джерелознавчу базу, проаналізовано низку робіт вітчизняних і зарубіжних дослідників XIX ст. - поч. XX ст. (В. Вільсон, С. Дністрянський, А. Дюнан, К. Эккарстгаузен, М. Карєєв, Г. Кольб, М. Ковалевський, Ш. Сеньобос, К. Тахтарєв та ін.), які були маловідомі для вітчизняної правничої науки. Заразом, робота містить й аналіз праць мислителів і правників сучасності, присвячених дослідженню питань майбутнього референдумів і безпосередньої демократії в цілому. Автори рецензованої монографії також комплексно проаналізували міжнародні стандарти референдної демократії, утілені в Кодексі належної практики щодо референдумів (CDL-AD(2007)008 rev) та інших важливих міжнародних документів.

Рещензія надійшиа до редколегї 29.11.2020

Коваленко В. В., доктор юридических наук, профессор, заслуженный юрист Украины, член-корреспондент НАПрН Украины, ведущий научный сотрудник лаборатории авторского права и информационных технологий Научно-исследовательского центра судебной экспертизы по вопросам интеллектуальной собственности

Министерства юстиции Украины (г. Киев, Украина)

\section{НОВЫЕ НАУЧНЫЕ ПОДХОДЫ К ИССЛЕДОВАНИЮ ВСЕУКРАИНСКОГО РЕФЕРЕНДУМА В СИСТЕМЕ РЕФЕРЕНДНОЙ ДЕМОКРАТИИ}

Рецензия на кн.: Стефанчук Р. О., Федоренко В. Л. Всеукраїнський референдум у системі референдної демократії : монографія. Одеса : Видавничий дім «Гальветика», 2019. 252 c. 


\section{Kovalenko V., Doctor of Law, Professor, Honored Lawyer of Ukraine, Corresponding Member of the National Academy of Legal Sciences of Ukraine \\ Leading Researcher of the Laboratory of Copyright and Information Technologies of the Research Center for Forensic Intellectual Property of the Ministry of Justice of Ukraine \\ (Kyiv, Ukraine) \\ NEW SCIENTIFIC APPROACHES TO THE STUDY OF THE ALL-UKRAINIAN REFERENDUM IN THE SYSTEM OF REFERENDUM DEMOCRACY}

Review of the book: Stefanchuk, R. O., Fedorenko, V. L. (2019) All-Ukrainian referendum in the system of referendum democracy : monograph. Odesa : Galvetica Publishing House. 252 p. [in Ukrainian].

DOI: $10.33766 / 2524-0323.92 .349-352$

УДК 343.13

\begin{abstract}
Т. О. Лоскутов, доктор юридичних наук, доцент, професор кафедри організації досудового розслідування Криворізького навчально-наукового інституту Донецького юридичного інституту Міністерства внутрішніх справ України (м. Кривий Ріг, Україна) e-mail: timloskutov@ukr.net iDhttps:/ / orcid.org/0000-0002-2686-9201
\end{abstract}

\section{ЗАСТОСУВАННЯ ЗАХОДІВ ЗАБЕЗПЕЧЕННЯ КРИМІНАЛЬНОГО ПРОВАДЖЕННЯ СЛДДЧИМ СУДДЕЮ ТА СУДОМ}

Рецензія на кн.: Завтур В. А. Особливості доказування при застосуванні заходів забезпечення кримінального провадження слідчим суддею та судом: теорія і практика : монографія / В. А. Завтур. Одеса: Видавничий дім «Гельветика», 2020. 248 с.

Рецензія підготовлена на монографію «Особливості доказування при застосуванні заходів забезпечення кримінального провадження слідчим суддею та судом: теорія і практика», автором якої є кандидат юридичних наук, старший викладач кафедри кримінального процесу, детективної та оперативно-розшукової діяльності Національного університету «Одеська юридична академія». У монографії розкрито питання щодо рішення про застосування заходів забезпечення кримінального провадження в системі кримінально-процесуальних актів, кримінального процесуального доказування при розгляді слідчим суддею клопотань про застосування за- 